\title{
Influence of the Temperature, Pressure and Viscosity on the oil Measurement with Turbine Type Measurers
}

\author{
Magalí Araújo Damasceno ${ }^{1 *}$, Janaina Karla de Medeiros Penha ${ }^{1}$, Nivaldo Ferreira da Silva \\ Junior $^{1}$, Raimundo Nonato B. Felipe ${ }^{1}$, Renata Carla Tavares dos Santos Felipe ${ }^{1}$ and Gilson \\ Gomes de Medeiros ${ }^{1,2}$ \\ ${ }^{1}$ Centro Federal de Educação Tecnológica do Rio Grande do Norte - CEFET-RN; Av. Sen. Salgado Filho, 1559; \\ Tirol; Natal - RN - Brasil. ${ }^{2}$ Universidade Federal do Rio Grande do Norte - UFRN/DEQ;Campus Universitário; \\ Natal - $R N$ - Brasil
}

\begin{abstract}
The flow measurement of liquids and gases is a necessity in many industrial applications. There is a great amount of measurers for such purpose, as, for example, the coriolis, positive displacement and type turbine measurers. A measurer sufficiently used for the oil flow measurement is the turbine type, because it uses the proper extracted energy of the measured flow for its functioning, moreover is also used as standard for the calibration of other measurers. For this reason, it is important to study the parameters that influence the measurement process for turbine measurers. In Brazil, to measure the volume of oil, regardless the type of measurer, it is necessary to observe "Portaria Conjunta N". 1", of June 19, 2000, that approved the Technical Regulation of Measurement of Oil and Natural Gas, establishing the minimum conditions and requirements for the systems of oil and natural gas measurement, in order to get a measurement standard. As such, the present work has the objective of determining parameters that influence in the measurement of oil volumes using turbine measurers.
\end{abstract}

Key words: Oil, measurement, turbine

\section{INTRODUCTION}

The oil is the main worldwide energy source and the basic element for the modern industrial society. From its extraction, the fluid is measured to know the amount that each well and each field produces.

The Brazilian norm "Portaria Conjunta $N^{\circ} 1$ ", (ANP/INMETRO, 2000) approved the use of several fluid measurers, such as the measurers type positive displacement, coriolis and measurers type turbines. Other types of measurers can be used, since its use is duly authorized by the National Agency of Oil - ANP.
Each one of these tools has its proper principle of functioning and fields of application, determined by the work conditions, which include: type of fluid, temperature and other important factors.

Therefore, to get a true value of a measurement of oil, it is necessary to know the involved parameters in the process. The result of a measurement can be evaluated by statistics methods or through variation of the factors of which this result depends on, with the objective to guarantee the certainty in the measurement of the produced and transferred volumes.

The turbine types of the industrial series are used as the instrument of measurement for oil and its

\footnotetext{
* Author for correspondence
} 
derivatives and gases. There are several types of turbines, depending on the positioning of axle of the rotor in relation to the flow, as well as the methods of measuring their rotations.

Some turbine types are purely mechanical and others are equipped with sophisticated electronic secondary elements. The measurer turbine is also used as standard for the calibration of other measurers.

In this type of measurer, the exit of pulses is convenient for the direct totaling of the flow. The linear relation between the frequency and the flow results in great range of measuring (Ribeiro, 1997).

The conventional measurer is a type of turbine that is sufficiently used because the rotor is made with longitudinal axle to the flow, integral bifool and has approximately equal diameter to the one of the tubing, as seen in the figure 1 . It shows a great performance and the highest precision, linearity and repeatability, and is very much used for the calibration of other measurers (Ribeiro, 1997).

The measurer consists basically of a rotor with vanes that are put inside the perpendicular tubing the flow. The fluid to be measured stimulates the rotor and it makes it turn in a definite angular speed. The rotational speed of the vanes is directly proportional to the flow and can be detected by a mechanical or electric sensor, which can get the value of the flow from the passage of the blades of the rotor of the turbine.

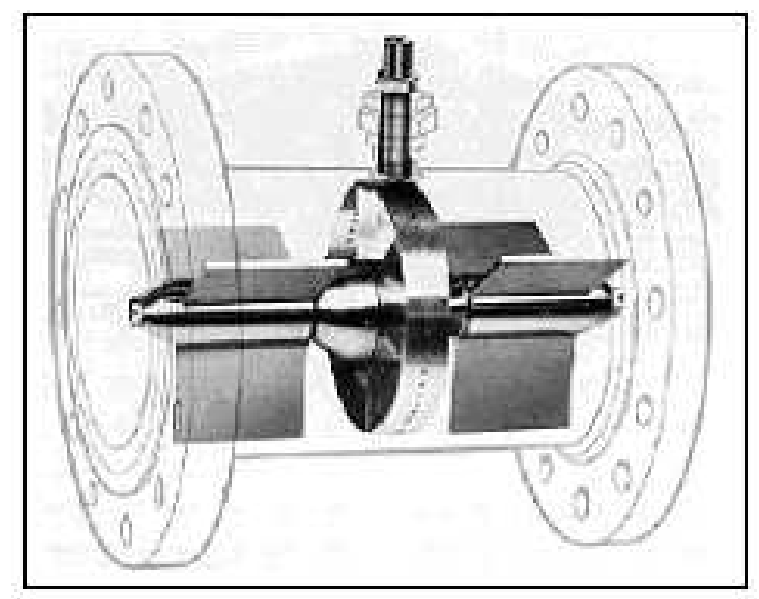

Figure 1 - Constituent parts of the conventional measurer turbine type. From Ribeiro (1997).
The exit signal is practically linear, therefore each pulse corresponds to one certain volume. The number of pulses for unit of flow is called factor $\mathrm{K}$ of the turbine. This factor varies according to the flow intensity, the pressure and the operating temperature.

This work aims to analyze the parameters that come to influence in the measurement of oil.

Three basic parameters of the measurers type turbine were evaluated: firstly, the influence of the temperature, which provides an error in case the density is not corrected in the measurement process and in case of bad distribution of the temperature in the fluid; the second factor is the influence of the viscosity, whose increase provokes a reduction of factor $\mathrm{K}$ of the measurer; and, finally, the influence of the pressure.

\section{METHODOLOGY}

The methodology used in this work consisted in the accomplishment of a bibliographical research on the oil measurer turbine, the norms that establish the measurement and correction, as well as a simulation of data, in order to evaluate the parameters that influence in the process of measurement of oil.

The study was developed on the basis of the standards established by the norms "Portaria Conjunta $\mathrm{N}^{\circ}$ 1" (ANP/INMETRO, 2000), ISO 4267 (1988) and the "Resolução n ${ }^{\circ}$ 06/70" (CNP, 1970), which aims to establish the reliability of the procedures of flow measurement of the Oil by turbine type measurers..

Influence of the temperature on the correction of the measured volume of oil

The temperature of the measured liquid affects the performance of the turbine, due to a mechanical effect caused by the expansion or thermal contraction of the box and the turbine, when the operating temperature is different from the temperature of calibration. The variation of the temperature affects the physical properties of the measured fluid, such as its vapor pressure, density and viscosity.

The right measurement of the temperature is one of the most important factors in the operations, in view of that small variations can present great errors because of bad distribution of the temperature of the fluid, intervening the 
conversion of the volumes of the products for the temperature standard of $20{ }^{\circ} \mathrm{C}$, adopted as temperature of reference for the measurement of derivatives of the oil, in accordance with "Portaria no 27" (MIC, 1959).

Therefore, it is also necessary to measure the temperature of the product and to correct the volume at room temperature for the standard temperature, as mentioned in the previous paragraph. This correction uses a factor which is obtained from the collecting of a representative sample of the product, in view of the correction of the thermal expansion among the temperature reference and the temperature of measurement, through the correction of the density of the oil measured in the conditions of work to $20{ }^{\circ} \mathrm{C}$, according the norm of the National Council of Petroleum, "Resolução no 06/70" (CNP, 1970).

The absence of correction of the density generates an error in function of the temperature of the oil. Therefore, the need for this correction for the attainment of more accurate measured volumes is evident.

For the simulation, a sample of oil with estimated density of $0.7852 \mathrm{~g} / \mathrm{m}^{3}$ (representative average value) in the work condition was used, for the volumes established in table 1 . On the other hand, for the determination of the influence of the temperature in the correction of the measured volume of oil, the temperatures of work were considered in accordance with table 2 .

Table 1 - Dimensions of the analyzed measurers.

\begin{tabular}{c|cc}
\hline \multirow{2}{*}{$\begin{array}{c}\text { Identification of the } \\
\text { measurer }\end{array}$} & \multicolumn{2}{|c}{ Measurer specifications } \\
\cline { 2 - 3 } & $\begin{array}{c}\text { Nominal diameter of the tubing } \\
(\mathbf{m m})\end{array}$ & $\begin{array}{c}\text { Maximum flow } \\
\left(\mathbf{m}^{\mathbf{3}} \mathbf{/ h}\right)\end{array}$ \\
\hline M1 & 25 & 2 \\
M2 & 250 & 1200 \\
M3 & 500 & 6000 \\
\hline
\end{tabular}

Tabela 2 - Operation temperatures.

\begin{tabular}{cc} 
& Temperatures $\left({ }^{\circ} \mathbf{C}\right)$ \\
\hline Temperature 1 & 26 \\
Temperature 2 & 28 \\
Temperature 3 & 30 \\
Temperature 4 & 32 \\
Temperature 5 & 34 \\
Temperature 6 & 36 \\
\hline
\end{tabular}

Influence of viscosity on the correction of the measured volume of oil

The value of a measurement made for a measurer turbine is affected by changes in the viscosity of the fluid to be measured. The viscosity of the liquid is dependent on the temperature. Therefore, with the increase of the temperature a reduction of viscosity occurs and, consequently, the performance of the turbine is modified.

The measurement of kinematics viscosity is desirable when the operation occurs at a great range of temperature or at very low flows, and mainly when a great precision is desired.

The linear range of the measurer is one of the more affected parameters by the variation of viscosity, specially if the turbine presents parallel blades. This variation depends on the type of the rotor. For a kinematics viscosity above of $100 \mathrm{cSt}$, the turbine does not present the linear region (Ribeiro, 1997).

For the same pressure, the flow diminishes when the fluid viscosity increases. For a given flow, an increase of viscosity can present a reduction in the factor $\mathrm{K}$ of the measurer.

\section{Influence of the pressure on the correction of the measured volume of oil}

When the compressibility has a considerable value, it is important to measure the pressure to allow the correction of the measured flow.

The variation of the pressure causes changes in the physical dimensions of the measurer due to pressure made by the liquid, leading to an 
expansion or contraction of the box measurer, as established by the norm ISO 2715 (1980).

According to Ribeiro (1997), if the pressure of the liquid approaches to its vapor pressure, the local vaporization can happen soon behind the vanes of the rotor. This provokes an artificial increase in the speed of the fluid, which can drastically affect the factor $\mathrm{K}$.

The variation of the pressure in meter is proportional to the square of the flow. To have a constant entrance, a maximum flow is necessary, in which the measuring turbine can be operated with an acceptable margin of error. This happens due to the effect caused by the cavitation in the measurer, that is the boiling of the liquid originated for the reduction in the pressure, instead of the temperature rise.

It is important to remember that, for any installation, the downstream turbine flow needs to be kept to a minimum pressure to prevent a variation in the calibration factor due the cavitation. The minimum pressure after the turbine is function of the vapor pressure of the liquid and the presence of dissolved gases.

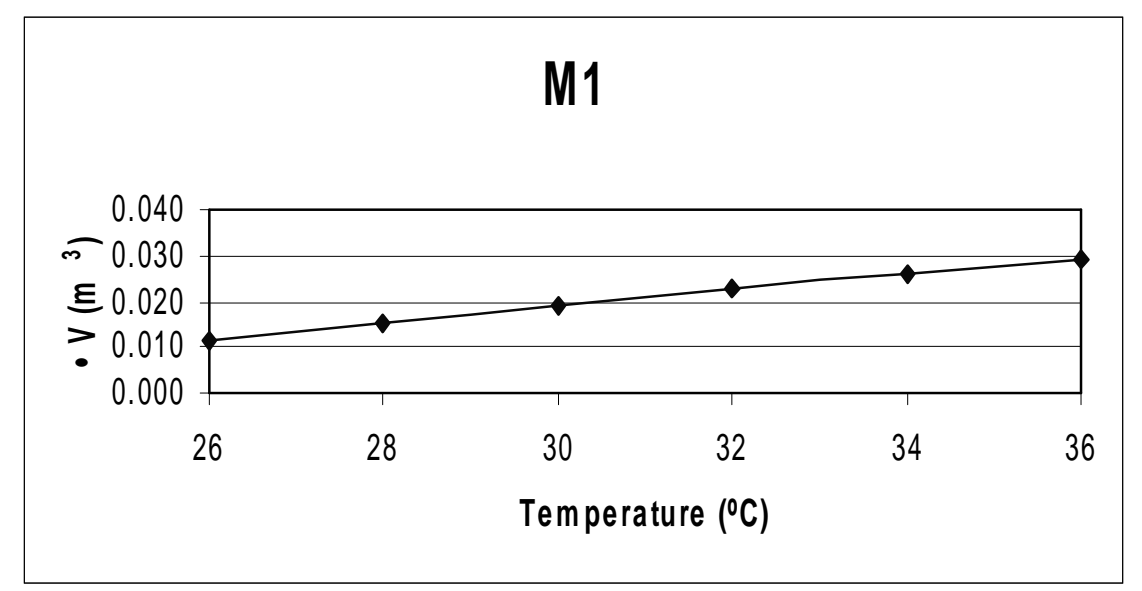

Figure 2 - Variation of the measured volume by the M1 measurer due to the correction of the density for the reference temperature, after one hour operation.

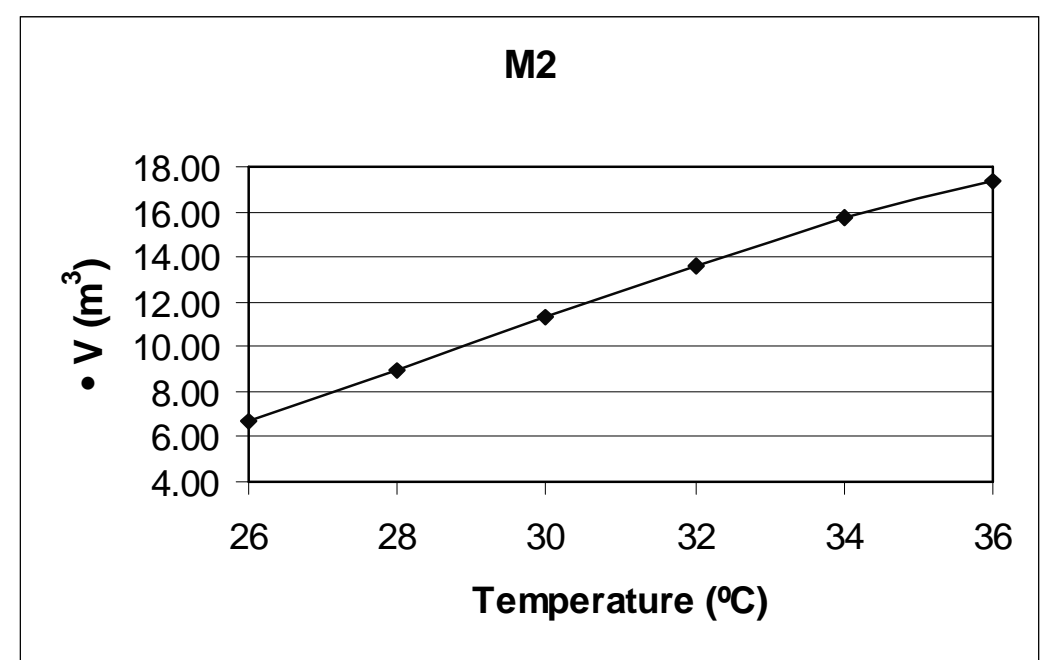

Figure 3 - Variation of the measured volume by the M2 measurer due to the correction of the density for the reference temperature, after one hour operation. 


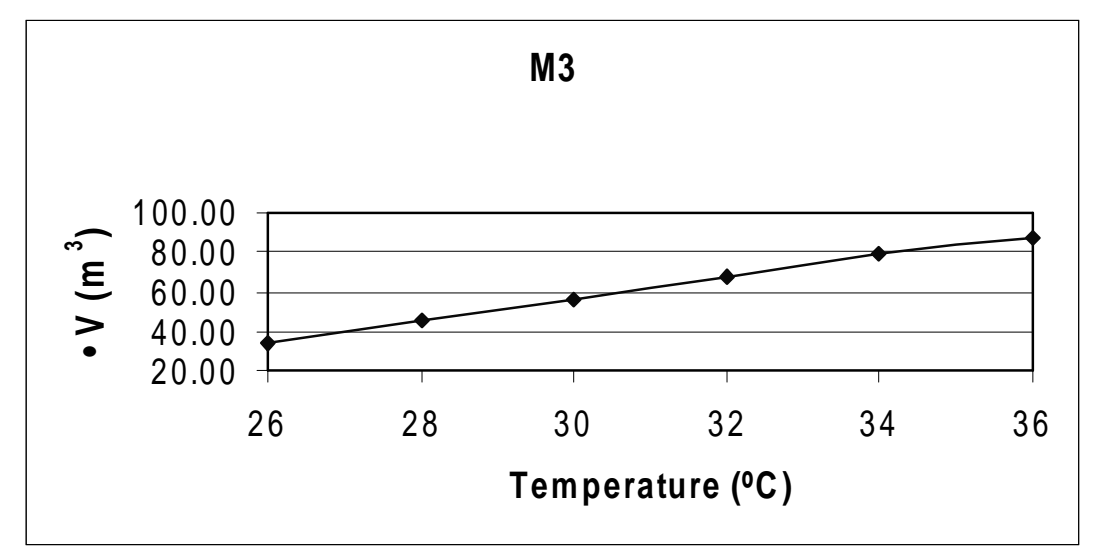

Figure 4 - Variation of the measured volume by the M3 measurer due to the correction of the density for the reference temperature, after one hour operation.

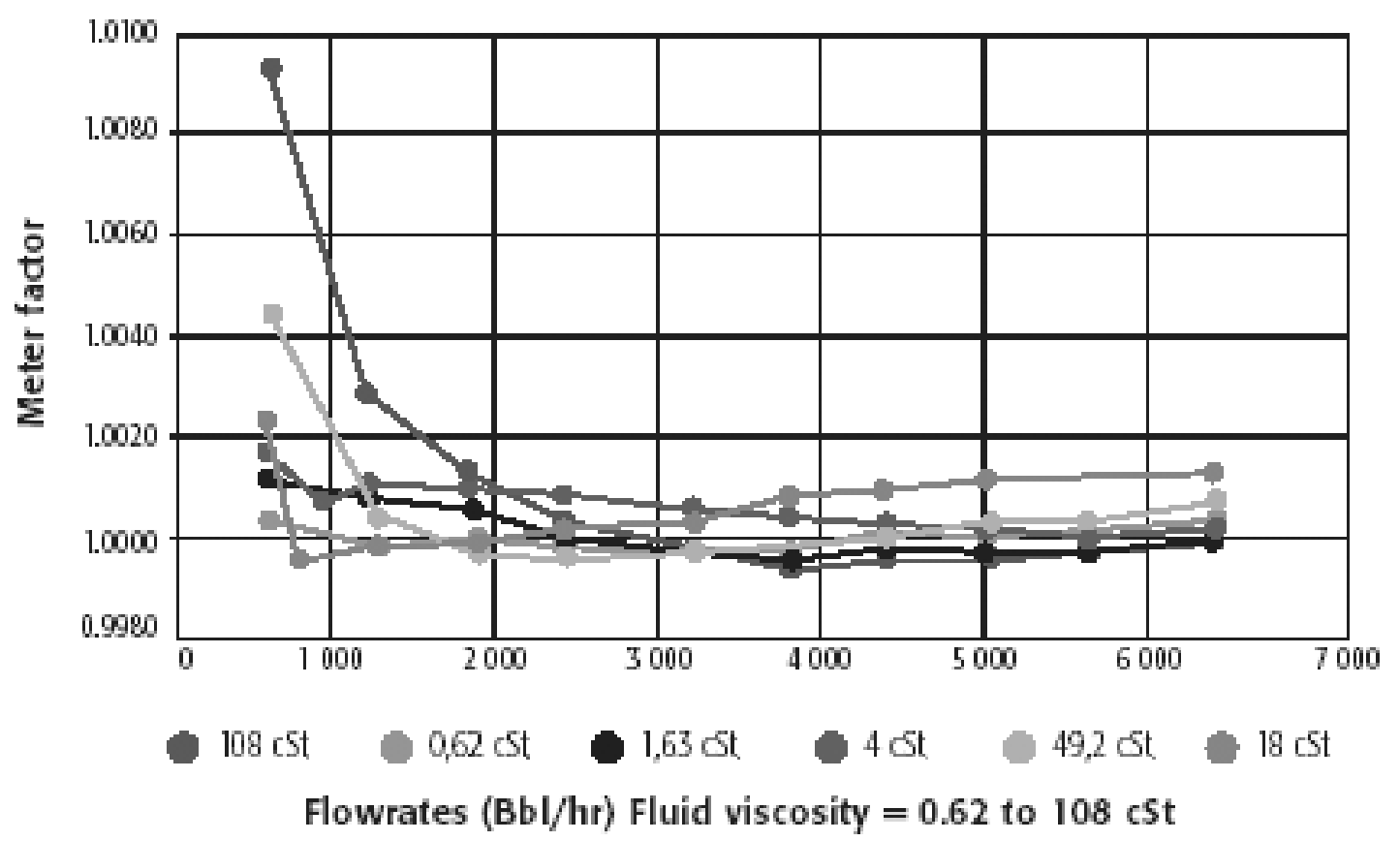

Figure 5 - Influence of viscosity on the meter factor of the turbine (Faure Herman, 2004).

\section{RESULTS AND DISCUSSION}

\section{Influence of the temperature}

The obtained results from the simulation of the measured volumes of oil, according to the norm "Portaria Conjunta $\mathrm{N}^{\circ}$ 01" (ANP/INMETRO, 2000), must be corrected to the reference temperature $\left(20^{\circ} \mathrm{C}\right)$.

Taking an oil sample with density of $0.7852 \mathrm{~g} / \mathrm{m}^{3}$ (representative average value), it is observed that the variation of volume, due to the correction in function of the operation temperature, is linear, as shown in Figures 2, 3 and 4, when the measurement system is evaluated in the range from $26^{\circ} \mathrm{C}$ to $36^{\circ} \mathrm{C}$.

It can be stated that, if the density is not corrected from the actual oil temperature to the reference temperature, an error is generated, thus influencing in the measurement of the oil volume. So, it can be concluded that this correction is necessary to obtain more accurate measured volumes. 


\section{Influence of the oil viscosity}

Figure 5 shows the variation of the meter factor (correction factor of the measurer) in function of the flow, for different oil viscosities, when a 8" diameter measurer is used (Faure Herman, 2004). It can observed that, for a viscosity of $108 \mathrm{cSt}$ (blue curve), an substancial reduction in the meter factor occurs reaching the flow of $2500 \mathrm{Bbl} / \mathrm{h}$, and that above this value the factor remains steady.

For an intermediate viscosity, as $49.2 \mathrm{cSt}$ (green curve), we can say that its result is not different from the blue curve. The meter factor, even lower than $108 \mathrm{cSt}$, also decreases up to $2000 \mathrm{Bbl} / \mathrm{h}$, remaining steady to higher flow values. For a viscosity of $0.62 \mathrm{cSt}$ (gray curve), the meter factor practically remains steady.

Figure 6 shows the influence of viscosity in the pressure drop (loss of load) of the turbine measurer type. It can be observed that this drop varies not linearly with viscosity. For the range of viscosity from 0 to $100 \mathrm{cSt}$, the drop varied from 0.2 to 0.5 bar.

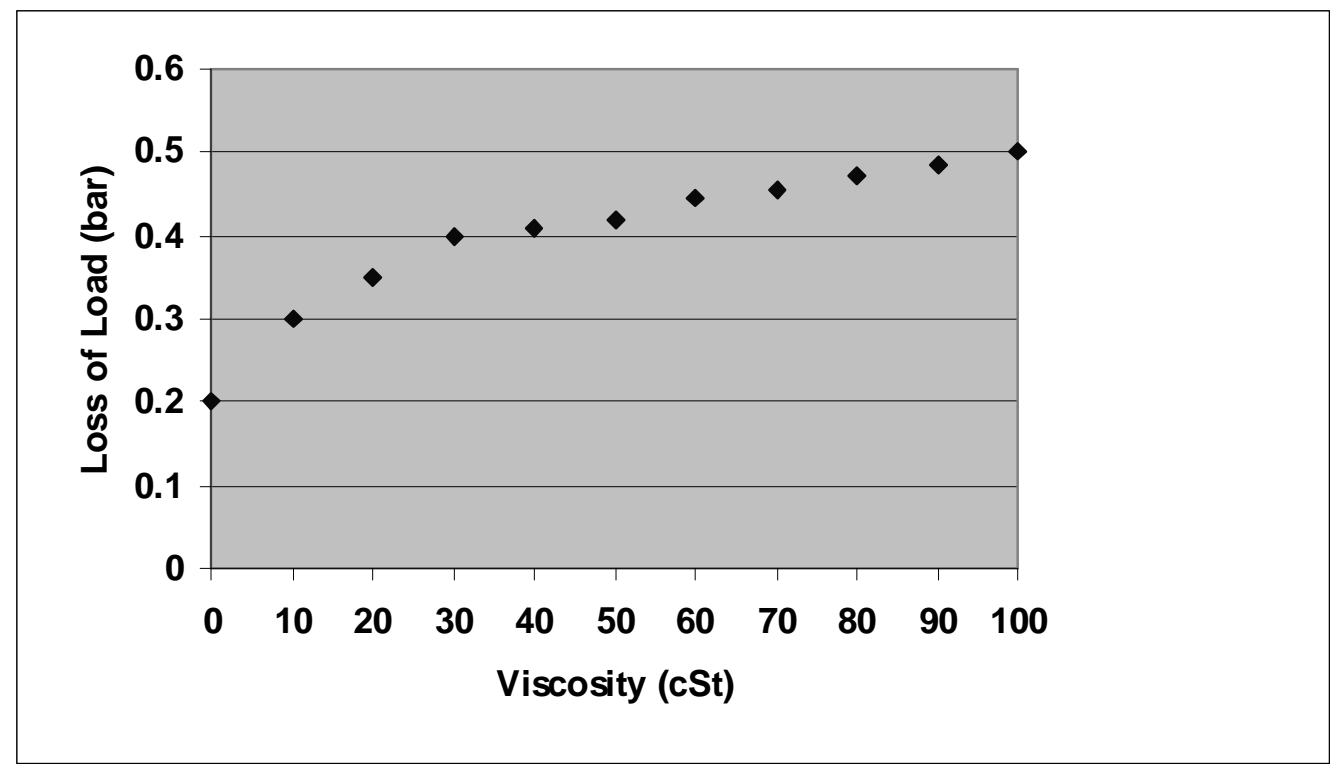

Figure 6 - Pressure drop as function of viscosity. Adapted from Faure Herman (2004).

\section{CONCLUSION}

O estudo dos parâmetros, variabilidades e a forma de apresentação dos resultados, proporcionaram uma visão geral do desempenho do medidor turbina, assim como a simulação de dados contribuiu para a quantificação destes resultados observados. Caracterizando-se as variabilidades quanto ao desempenho do medidor, bem como suas faixas de influências, é possível concretizar as aplicações de medidores turbinas na indústria de petróleo. A forma de apresentação dos resultados irá permitir a comparação de desempenho de medidores turbinas com outros medidores de vazão.

The study of the influence of the analyzed parameters provided a general view about the performance of the turbine measurer type. The data simulation contributed for the quantification of the results. The characterization of the performance of the measurers in the face of the variations in those parameters, as well as its ranges of influence, made the applications of measurer turbines in the oil industry possible. The presentation of the results will allow the comparison between the performance of turbine and other flow measurers.

\section{ACKNOWLEDGEMENTS}

This work was undertaken as part of the research project "Uncertainty of Measurement of Oil and Natural Gas", included in the Rede de Instrumentação e Controle (Rede 10/05). The authors are grateful to the Finep, $\mathrm{CNPq} e$ CENPES-Petrobras, for the financial support, which was essential for its accomplishment. 


\section{RESUMO}

A medição de fluxo em líquidos e gases é uma necessidade em muitas aplicações industriais. Existe uma grande quantidade de medidores para tal finalidade, como, por exemplo, os medidores de velocidade tipo turbina, deslocamento positivo e coriolis. Um medidor bastante utilizado para a medição de vazão de petróleo é o tipo turbina, porque utiliza a própria energia extraída da vazão medida para seu funcionamento. Além disso, é também usado como padrão para a calibração de outros medidores. Daí a importância de se estudar os parâmetros que influenciam o processo de medição por medidores tipo turbina. Para se medir o volume de petróleo, independentemente do tipo de medidor, é necessário observar o que determina a Portaria Conjunta $\mathrm{N}^{\mathrm{o}}$. 1, de 19 de junho de 2000, que aprovou o Regulamento Técnico de Medição de Petróleo e Gás Natural, estabelecendo as condições e requisitos mínimos para os sistemas de medição de petróleo e gás natural, a fim de se obter um padrão de medição. Com isso, este trabalho visa determinar os parâmetros que influenciam na medição de volumes de petróleo utilizando medidores do tipo turbina.

\section{REFERENCES}

ANP/INMETRO (2000), Portaria Conjunta n. 01. Regulamento técnico da medição de petróleo e gás natural.

CNP (1970), Resolução n. 06/70. Tabelas de correção de volume do petróleo e derivados.

Delmée. G. J. (1982), Manual de medição de vazão. São Paulo: Edgard Blücher.

Faure Herman (2004), HELIFLU ${ }^{T M} T Z N$, the dedicated turbine flowmeter for custody transfer measurement. Disp. in: http://www.faureherman.com/download/ tzn.pdf.

ISO 2715 (1980), Liquid Hydrocarbons - Volumetric Measurement by Turbine Meter Systems.

ISO 4267 (1988), Petroleum and liquid petroleum products - Calculation of oil quantities - Part 2: Dynamic measurement.

Ministério da Indústria e Comércio (1959), Portaria n. $27 / 59$.

Ribeiro, M. A. (1997), Medição de vazão fundamentos e aplicações. Salvador: Tek Treinamento \& Consultoria.

Received: July 29, 2005; Revised: September 05, 2005; Accepted: November 22, 2005. 


\section{FOLHA}

EM

BRANCO 